\title{
Analysis of Pre-service Science Teachers' Digital Literacy Through Workshop of Optimization Microsoft Office Software Usage
}

\author{
Diniya $^{1 *}$, Niki Dian Permana $\mathbf{P}^{\mathbf{2}}$, Susilawati ${ }^{3}$, Theresia Lidya Nova ${ }^{4}$, Aldeva Ilhami ${ }^{\mathbf{5}}$ \\ 1,2,3,4,5 Tadris IPA, Universitas Islam Negeri Sultan Syarif Kasim Riau, Jl. H.R Soebrantas KM \\ 15 No. 155, Pekanbaru, Riau, 28293 \\ *Correspondence: diniya@uin-suska.ac.id
}

\begin{tabular}{ll}
\hline Keywords: & Thstract \\
Digital literacy & The present study was carried out to analyze the digital literacy for pre-service natural \\
Microsoft office & software. This study explored an experimental method with the one-group pretest- \\
Workshop & posttest design. The current research adopted 25 students as the pre-service natural \\
science teachers in the Natural Sciences Study Program of the Tarbiyah and Teaching \\
Faculty of the Sultan Syarif Kasim Riau State Islamic University. The data were \\
collected through providing instruments of multiple-choice tests on the pretest and \\
posttest, questionnaire, and interview to measure the improvement of digital literacy. \\
To analyze the data, a technique to calculate the mean score of the normalized gain (N- \\
gain) was performed. The findings disclosed that the mean score of N-gain digital \\
literacy for pre-service natural science teachers was 0.70 with the high category. Based \\
on results obtained in this line of research, it is therefore concluded that there was an \\
improvement in the digital literacy for pre-service natural science teachers with high \\
category through the workshop on optimizing the use of Microsoft Office software.
\end{tabular}

To cite this article:

Diniya, D., Permana P, N. D., Susilawati, S., Nova, T. L., Ilhami, A. (2020). Analysis of Preservice Science Teachers' Digital Literacy Through Workshop of Optimization Microsoft Office Software Usage. Thabiea: Journal of Natural Science Teaching, 3(1), 70-78.

\section{Introduction}

Education 4.0 which is very lively echoed today is a new breakthrough in the world of education that supports the realization of intelligent education and equitable distribution of quality education, expansion of access, and relevance of the use of technology in learning (LLDIKTI, 2019). Education 4.0 is also very demanding for the skills possessed by each student. The formulated skills include problem-solving skills, teamwork skills, communication skills in the form of the ability to argue (communication), critical thinking skills, creativity, literacy, digital literacy, leadership, foreign languages, and emotional control.

Literacy skills are all the skills needed for reading and writing concepts that have been or are being learned. Literacy is in the most core position in understanding a discourse. Therefore, this skill must be possessed by students to get a job or education at the university level (Spiers et al., 2018). In this educational era 4.0, students shall be able to master a new skill called digital literacy.

Digital literacy refers to an individual's ability to use information technology and the internet to find, evaluate, share, and create content. Digital literacy is very closely related to the use of technology.This is in accordance with Shannon's statement (2017) that the devices 
included in digital literacy are smartphones, tablets, laptops, and computers, each of which functions to communicate, express, collaborate and advocate. Digital literacy is an initial stepping stone to show the academic performance of pre-service teachers. In line with the statement of Yazon et al., (2019) that digital literacy in practice requires digital competence. Digital competence includes self-confidence and critical attitude in the use of information technology, leisure, and communication. It can be declared that digital literacy is necessary to be equal to digital competence. By the statements of Martin and Grudziecki (2006) and Siljebo (2013) that there are several fundamental skills in Communication and Information Technology (ICT) known as the use of computers to refuse, access, store, produce, display and change information. Another essential thing is the use of computers to communicate and participate in networks through the internet. And therefore, it can be interpreted that digital competence must be supported by digital literacy.

Digital literacy means having the skills of caring, attitude and individual ability to use digital tools and facilities properly by identifying, accessing, managing, integrating, evaluating, analyzing and synthesizing digital resources, forming new knowledge, making available and communicating with each other between one and the other, thus they will be able to form a constructive social environment soon (Martin \& Grudziecki, 2006). There are several levels of digital literacy. Look at Figure 1 below.

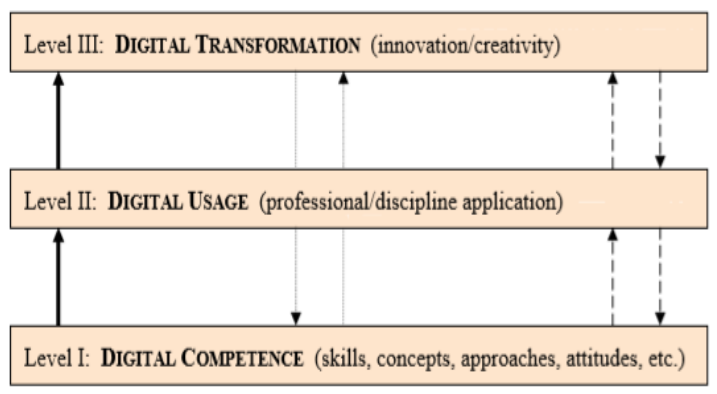

Figure 1. Digital Literacy Level

This digital competence is the core foundation of digital literacy itself. At this level, the scope of digital literacy is still very broad, with core skills in criticizing, evaluating, and conceptual approaches, as well as attitudes and concerns. Someone or a group uses this digital capability according to their needs and many will get new experiences that come from their lives(Martin \& Grudziecki, 2006). More details can be seen in Figure 3 below. This is what is needed by prospective teachers in the Natural Sciences Tadris Study Program at the Faculty of UIN Suska Riau. An increase in digital literacy in prospective teachers will be very helpful in completing assignments and scientific work following their needs.

Digital usage is the application of digital literacy in a more specific and professional context. At this level, digital users are generally in the professional category, use digital with discipline, and even have a digital community. People at this level have used digital tools to solve social problems in the community. For example, Google Classroom and Edmodo which utilize e-learning application. The existence of the team making the application to answer the problem that if the class cannot be carried out face to face, it can replace the class through e- 
learning. The digital transformation refers to the advanced level of the second level. At this level, people have been able to develop and create innovations through digital tools.

Digital literacy competence is also necessary by anyone in this period not only for students but also for pre-service teachers. In line with Shanonn's explanation (2017) that at this time it is mainly necessary for the students to practice competencies and improve their knowledge through digital tools. Bhatt and De Roock (2013) have also suggested that the practice of digital literacy was congruent with learning in schools. Thus, it is considered important for teachers to be able to improve their digital literacy skills, and in turn, students can master such skills. Bloom's taxonomy can be applied to digital literacy to show a student's creativity and self-efficacy. Following the statement of Prior et al., (2016) that the fact is digital literacy can improve student learning management and self-efficacy.

There are other aspects, while the improvement in digital literacy is also closely related to an individual's cognitive skills. Look at the following Figure 2:

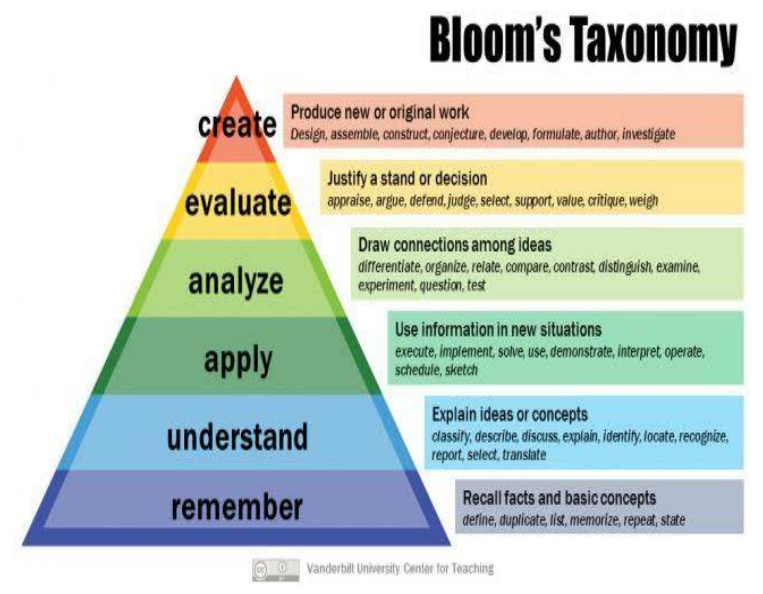

Figure 2. Bloom's Taxonomy

In Figure 2 it can be seen that there are differences in the cognitive aspects of the process. In Bloom's taxonomy can be associated with digital literacy (Shannon, 2017). As for what is included in digital literacy are all aspects of cognitive skills such as the ability to analyze, create, and evaluate. Such formulated three cognitive aspects are included in the High Order Thinking Skills while the ability to remember, understand, and apply is included in the Low Order Thinking Skills. Thus it can be interpreted that digital literacy involves many cognitive processes. Bloom's taxonomic revision by Krathwohl, et.al (2002) explains that each aspect of the cognitive becomes a verb which means that there is a change from the word copyright to create, analyze and evaluate. The cognitive aspect refers to the interaction between the user and the tool itself. For example, laptops as tools and users as users. Equal knowledge and competency of users in digital tools will lead to interactions that will produce digital literacy in the high category.

Therefore, digital literacy and digital competence shall be equal thus there is no gap between them. In this regard, the importance of competency to enhance for pre-service teachers because during the classroom activities and thesis preparation will mostly use either computer or laptop. Competence in using a laptop as a digital tool and Microsoft Office 
software included in level one or as a core foundation concept in digital literacy skills should be the focus of prospective teachers. If they are unable to master such competence, they will possess difficulty in preparing their thesis. And therefore, digital literacy competence will also greatly affect the modern workplace in the future.

Research on this issue has been mostly conducted by several educational researchers. This was stated by Spante et al., (2018) and Martin and Grudziecki (2006) that there have been several studies related to digital literacy, even since the 1990s educational researchers in the world. For instance, Kubiatko's (2007) study disclosed that there was an improvement in digital literacy among students through the use of computers and the internet. Kubiatko also figured out that female students used the internet more while at school such as in the library while male students use the internet more at home.

Kaeophanuek et al., (2018) in his study over 400 students in Thailand showed that the ability to use digital devices was in good category and the ability to receive digital information was in the high category. Johnson Oseghale and John (2014) in their study, its results mentioned that students taught using computers have better digital literacy skills than students who are not taught using computers. The researchers would also add that students who are not addicted to computers possess better digital literacy skills than students who are addicted to using computers. Tang and Chaw (2015) found that students nowadays must own the ability to use digital tools and reuse digital competencies as core skills. Their research also found a gap between competence and digital knowledge that should remain balance.

Research conducted by Yazon et al., (2019) demonstrated that pre-service teachers who master digital literacy skills would greatly support research productivity. This is because someone who has good digital literacy skills will be able to use, complete, present, and publish an article following established rules.

Based on the results obtained in this line of observations for three months, researchers found that about 70 percent of prospective teachers in the Natural Sciences Study Program was still not proficient in operating Microsoft Office software. More specifically, pre-service teachers are still less adept at integrating the use of Microsoft Office software in the preparation of daily assignments in the form of papers. This is indicated by the fact that there are still prospective teachers who collect paper assignments via email with documents separated from one chapter to another. Though these documents can be combined in one document using the Page Break menu and Page Number in Microsoft Office Word software. Writing the table of contents is still manual even though you can use the Reference menu in Microsoft Office Word software in its preparation. At this level, a prospective teacher should be proficient in operating Microsoft Office software. This is because there are numbers of assignments, thesis, or other scientific works that must be prepared by a prospective teacher using Microsoft Office software.

Based on these problems, the researchers conduct workshop activities aimed at improving the digital literacy skills of pre-service natural science teachers in the Natural Sciences Tadris Study Program at the Faculty of Tarbiyah and Teacher Workshop at the Sultan Syarif Kasim Riau State Islamic University. 


\section{Method}

The current research explored the experimental method. This method has the characteristics of studying the state of an object, in which it was not possible to control all relevant variables except the variables studied (Sugiyono, 2013; Fraenkel, Wallen \& Hyun, 2012).

The description of improving the digital literacy ability of pre-service teachers is received by the research design in the one-group pretest-posttest design (Fraenkel \& Wallen, 2012). In this formulated study, one class was employed with the initial ability measured first through a prior pretest the treatment, and the post-test was given. Measurements were designated at the beginning and the end of the workshop.

Table 1. Research Design of the One-Group Pretest-Postest Design

\begin{tabular}{ccc}
\hline $\mathbf{O}$ & $\mathbf{X}$ & $\mathbf{O}$ \\
\hline Pre-test & Treatment & Post-test \\
\hline
\end{tabular}

Notes:

X : Microsoft OfficeWorkshop

$\mathrm{O} \quad$ : pretest or posttest

A population is a large group where the sample is taken and it is expected that the results can be generalized to the population. Samples are the number of living people or other objects taken from populations. The sample shall represent the population or can represent the population (Fraenkel \& Wallen, 2012, p. 91). According to Neolaka (2014), the population is a generalization area in the form of the subject or object under study to study while the sample is a portion of the population under study. The population in this study were all prospective teacher students in the Natural Sciences Tadris Study Program at the Faculty of Tarbiyah and Teacher Workshop at the Sultan Syarif Kasim Riau State Islamic University. Conducted through a purposive sampling technique, there were 25 students referred to preservice teachers of the Natural Sciences Tadris Study Program at the Faculty of Tarbiyah and Teacher Workshop who would prepare a final project or undergraduate thesis. According to Fraenkel and Wallen (2012), there are sometimes conditions that make it impossible to randomize a whole individual from the population. Random and stratified random sample selection cannot be used due to certain criteria, administrative requirements, or other limitations.

The independent variable in this study is a workshop in using Microsoft Office software while the dependent variable is digital literacy capabilities. The research instrument is a data collection tool in research (Fraenkel, Wallen, \& Hyun, 2012; Sudjana \& Ibrahim, 2014; Sugiyono, 2013). In this study, before the data were obtained, a research instrument was made in the form of a test instrument. The test instrument used in this study was a digital literacy test at level 1. Digital literacy test in the form of mastery of concepts related to the use of Microsoft Office software in the form of multiple-choice questions that have been validated. The multiple-choice questions are chosen according to the digital literacy assessment used to measure digital literacy capabilities by the Microsoft platform (www.microsoft.com/en-us/digitalliteracy/assessment). The questions are 10 items given at the beginning and end of the workshop. At the beginning of the workshop, a pretest was given 
to measure the mastery of concepts related to using Microsoft Office software. The final test (posttest) is done at the end after the treatment is given. The preparation of the test questions is guided by the thesis writing manual of the Tarbiyah and Teaching Faculty of the Sultan Syarif Kasim Riau State Islamic University.

\section{Results and Discussion}

Processing test data begins by analyzing the results of the pre-test. The objective is to determine the initial ability of pre-service natural science teachers related to the use of Microsoft Office software and then proceed with the post-test to observe the differences that occur before and after the given treatment.

Table 2. Recapitulation Score of Pre-test and Post-test

\begin{tabular}{|lcc}
\hline \multirow{2}{*}{ Component } & \multicolumn{2}{c}{ Score } \\
\cline { 2 - 3 } & Pre-test & Post-test \\
\hline Mean & 21,90 & 74,76 \\
\hline Maximun Score & 50,00 & 100,00 \\
\hline Minimum Score & 10,00 & 50,00 \\
\hline N-Gain & \multicolumn{2}{c}{0,70} \\
\hline
\end{tabular}

Based on Table 3, from 25 pre-service teachers (students) who took the pre-test and post-test, it can be seen that the mean score of the initial ability test using Microsoft Office software was 21.90. Such a score is obtained before the workshop is carried out. Afterward, students are given the post-test to measure the final ability. The mean score of the final test to use Microsoft Office software was 74.76. Based on these data it is therefore concluded that there is an improvement in digital literacy after the workshop in the use of Microsoft Office software for pre-service science teachers, For further details on the improvement in the participants' pretest and posttest scores can be seen in the following figure:

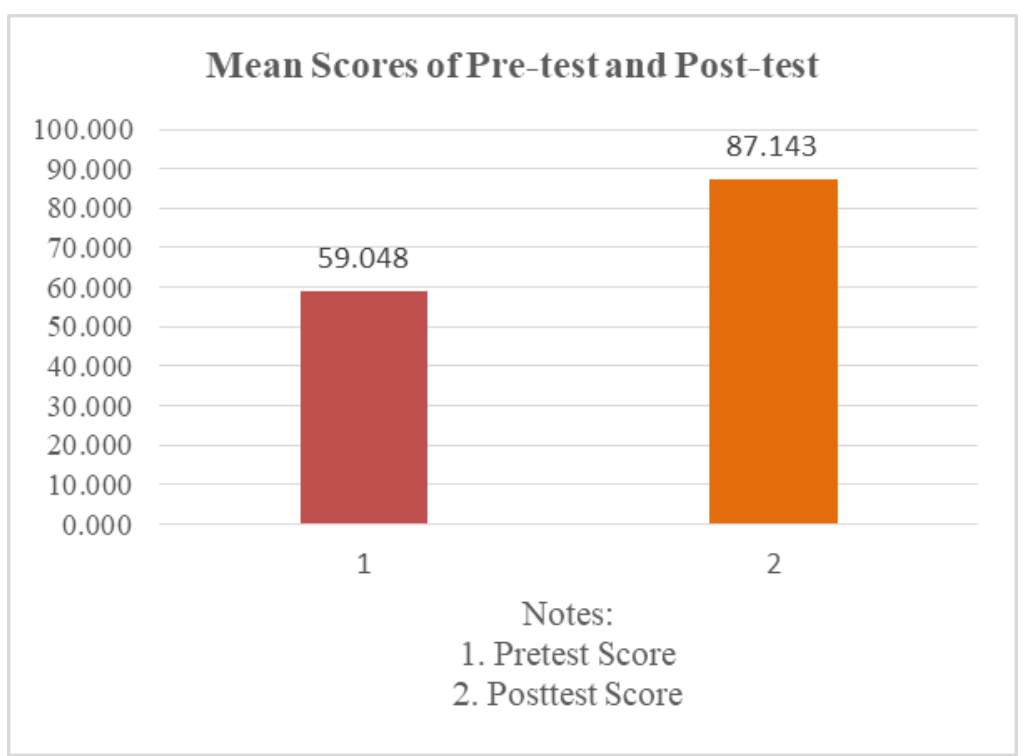

Figure 3. Graph of Competence Improvement among pre-service teachers through Microsoft Office software 
Based on Figure 3, it can be concluded that there is an improvement in the average digital literacy in using Microsoft Office software.

The magnitude of the score of the improvement (gain) indicated that each pre-service teacher who attended Microsoft Office software workshop have increased. Nevertheless, high gain or low gain does not necessarily reflect the digital literacy ability of prospective teachers in using Microsoft Office software in the high or low category. However, the N-gain value could indicate the achievement of ability. Therefore, it is not enough to figure out an increase alone, and therefore, it can be stated that the use of $\mathrm{N}$-gain scores is better than the use of data gain. Increased ability to use Microsoft Office software can be measured through the gain index obtained from the mean score of pretest and posttest calculated with the normalized gain of the mean score, for instance, the comparison of actual mean gain with maximum mean gain developed by Hake (1999).

$$
\mathrm{N}-\text { Gain }\langle g\rangle=\frac{\text { sccore } \left.\left._{\text {postest }}\right\rangle- \text { <score }_{\text {pretess }}\right\rangle}{\text { score } \left._{\max }-\text { score }_{\text {pretest }}\right\rangle}
$$

To see the quality of improving the ability concept of students understanding through the gain index criteria. Gain index criteria according to Lestari \& Yudhanegara (2015, p. 235).

Table 3. Category of Obtaining N-gain Scores

\begin{tabular}{cc}
\hline Limit & Category \\
\hline$(g) \leq 0,7$ & High \\
\hline $0,3<(g)<0,7$ & Middle \\
\hline$(g) \leq 0,3$ & Low \\
\hline
\end{tabular}

Based on Table 3, the $\mathrm{N}$-gain score was 0.70 , which indicated that an improvement in the digital literacy skills of pre-service teachers was in the high category. Furthermore, based on the questionnaire distributed to prospective teachers, $78.3 \%$ of pre-service teachers stated that the material presented during the workshop remained new, while $21.7 \%$ stated that the material presented was not new. The existence of such a formulated workshop can assist preservice teachers in writing scientific papers which demonstrated that as many as $100 \%$ of preservice teachers declared that the workshop can assist in writing scientific papers. As many as $100 \%$ of pre-service teachers also stated that such a formulated workshop can improve digital literacy skills through mastering Microsoft Office software. Based on the results of interviews, the pre-service teachers also stated that the workshop was significantly helpful in writing scientific papers. The workshop subject in terms of using Microsoft Office software is generally used by millions of people across the globe daily, yet there are still several functions necessary to enhance.

\section{Conclusion}

Based on results obtained in this line of research, it is therefore argued that there was an improvement in digital literacy competencies among pre-service teachers of the Natural Sciences Tadris Program after attending a workshop in using Microsoft Office software integrated with the thesis writing rules. Its improvement remained in the high category. 


\section{References}

Bhatt, I., \& De Roock, R. (2013). Capturing the sociomateriality of digital literacy events. Research in Learning Technology, 21(1063519). https://doi.org/10.3402/rlt.v21.21281

Fraenkel, J. R., Wallen, N. E., \& Hyun, H. H. (2012). How to design and Evaluate Research in education (8 ed.). Mc. Graw-Hill.

Hague, C., \& Payton, S. (2010). Digital Literacy Across The Curriculum. FutureLab. http://www.nfer.ac.uk

Hake, R. R. (2002). Relationship of Individual Student Normalized Learning Gains in Mechanics with Gender, High-School Physics, and Pretest Scores on Mathematics and Spatial Visualization. * †. Physics Education Research Conference, August 2002, 1-14.

Johnson Oseghale, D. A., \& John, D. O. (2014). The Impact of Computer Literacy on Students' Academic Performance in Senior Secondary Schools in Esan West Local Government Area, Edo State, Nigeria. Journal of Education and Human Development, 3(3), 265-270. https://doi.org/10.15640/jehd.v3n3a21

Kaeophanuek, S., Jaitip, N.-S., \& Nilsook, P. (2018). How to Enhance Digital Literacy Skills among Information Sciences Students. International Journal of Information and Education Technology, 8(4), 292-297. https://doi.org/10.18178/ijiet.2018.8.4.1050

Kubiatko, M. (2007). Information and computer literacy of high school students. Problems of Education in the 21st century, 2, 31-36.

Lestari, K. ., \& Yudhanegara, M. . (2015). Penelitian Pendidikan Matematika. PT Refika Aditama.

Martin, A., \& Grudziecki, J. (2006). DigEuLit: Concepts and Tools for Digital Literacy Development. Innovation in Teaching and Learning in Information and Computer Sciences, 5(4), 249-267. https://doi.org/10.11120/ital.2006.05040249

Prior, D. D., Mazanov, J., Meacheam, D., Heaslip, G., \& Hanson, J. (2016). Attitude, digital literacy and self efficacy: Flow-on effects for online learning behavior. Internet and Higher Education, 29, 91-97. https://doi.org/10.1016/j.iheduc.2016.01.001

Siljebo, J. (2013). Developing digital competence or exploring teaching with digital technologies? 68.

Spante, M., Hashemi, S. S., Lundin, M., \& Algers, A. (2018). Digital competence and digital literacy in higher education research: Systematic review of concept use. Cogent Education, 5(1), 1-21. https://doi.org/10.1080/2331186X.2018.1519143

Spires, H. a., Medlock Paul, C., \& Kerkhoff, S. N. (2018). Digital Literacy for the 21st Century. January, 12-21. https://doi.org/10.4018/978-1-5225-7659-4.ch002

Sugiyono. (2011). Metode Penelitian Kombinasi (Mixed methods). Alfabeta.

Sunarno, W. (2018). Pembelajaran IPA di Era Revolusi Industri 4 . 0. Prosidng Seminar Nasional Pendidikan Fisika IV 2018, 1-8.

Tang, C. M., \& Chaw, L. Y. (2015). Digital literacy and effective learning in a blended learning environment. Proceedings of the European Conference on e-Learning, ECEL, 
14(1), 601-610.

Yazon, A. D., Ang-Manaig, K., Buama, C. A. C., \& Tesoro, J. F. B. (2019). Digital literacy, digital competence and research productivity of educators. Universal Journal of Educational Research, 7(8), 1734-1743. https://doi.org/10.13189/ujer.2019.070812 